\title{
PRE- AND POSTOPERATIVE IN BARIATRIC SURGERY: SOME BIOCHEMICAL CHANGES
}

\author{
Pré e pós-operatório de cirurgia bariátrica: algumas alterações bioquímicas
}

Amanda Kaseker TEDESCO, Rafaela BIAZOTTO, Telma Souza e Silva GEBARA, Maria Paula Carlini CAMBI, Giorgio Alfredo Pedroso BARETTA

From the Clínica Baretta, Curitiba, PR, Brazil

\begin{abstract}
HEADINGS - Bariatric surgery. Dyslipidemia. Vitamin B12. Homocysteine. C reactive protein.
\end{abstract}

ABSTRACT - Background: The bariatric surgery may cause some nutritional deficiencies. Aim: To compare the serum levels of biochemical markers, in iimmediate post-surgical patients who were submitted to bariatric surgery. Methods: Non-concurrent prospective crosssectional study. The analysis investigated data in medical charts of pre-surgical and immediate post-surgical patients who were submitted to bariatric surgery, focusing total cholesterol, $\mathrm{HDL}$ cholesterol, LDL cholesterol, triglycerides, $C$ reactive protein, vitamin $B_{12}$ levels, folic acid, homocysteine values, iron and serum calcium at the referred period. Results: Twentynine patients of both genders were evaluated. It was observed weight loss from $108.53 \mathrm{~kg}$ to $78.69 \mathrm{~kg}$ after the procedure. The variable LDL-c had a significant difference, decreasing approximately $30.3 \mathrm{mg} / \mathrm{dl}$ after the surgery. The vitamin $B_{12}$ serum average levels went from $341.9 \mathrm{pg} / \mathrm{ml}$ to $667.2 \mathrm{pg} / \mathrm{ml}$. The triglycerides values were in a range of $129.6 \mathrm{mg} / \mathrm{dl}-173.3$ $\mathrm{mg} / \mathrm{dl}$, and $81.9 \mathrm{mg} / \mathrm{dl}-105.3 \mathrm{mg} / \mathrm{dl}$ at the pre- and postoperative respectively. CRP levels fall demonstrated reduction of inflammatory activity. The variable homocysteine was tested in a paired manner and it did not show a significant changing before or after, although it showed a strong correlation with LDL cholesterol. Conclusion: Eligible patients to bariatric surgery frequently present pre-nutritional deficiencies, having increased post-surgical risks when they don't follow an appropriate nutritional follow-up.

\section{Correspondence: \\ Maria Paula Carlini Cambi \\ E-mail: mpcarlini@hotmail.com \\ Financial source: none \\ Conflicts of interest: none \\ Received for publication: 04/02/2016 \\ Accepted for publication: 24/05/2016}

RESUMO - Racional: A cirurgia bariátrica pode causar deficiências nutricionais. Objetivo: Comparar os níveis séricos bioquímicos de pacientes submetidos à cirurgia bariátrica no pré e pós-operatório precoce. Métodos: Estudo transversal, retrospectivo não concorrente. A análise considerou a investigação de prontuários de pacientes submetidos à gastroplastia no período pré-operatório e pós-operatório precoce, analisando resultado bioquímicos de colesterol total, HDL colesterol, LDL colesterol, triglicérides, proteína $C$ reativa, dosagens de vitamina $B_{12}$ ácido fólico, valores de homocisteína, ferro e cálcio séricos, no referido período. Resultados: Compuseram a amostra 29 pacientes de ambos os sexos. Houve redução de peso após o procedimento cirúrgico com média de 108,53 kg para 78,69 kg. A variável LDL-c apresentou diferença significativa com diminuição de aproximadamente $30,3 \mathrm{mg} / \mathrm{dl}$ após a gastroplastia. Com relação à média de níveis séricos de vitamina $B_{12}$ ela passou de $341,9 \mathrm{pg} / \mathrm{ml}$ para $667,2 \mathrm{pg} / \mathrm{ml}$. Os valores de triglicérides encontravamse na faixa de $129,6 \mathrm{mg} / \mathrm{dl}-173,3 \mathrm{mg} / \mathrm{dl}$, e $81,9 \mathrm{mg} / \mathrm{dl}-105,3 \mathrm{mg} / \mathrm{dl}$ no pré e pós-cirúrgico, respectivamente. Foi evidenciada redução da atividade inflamatória verificada mediante queda dos níveis de PCR. A variável homocisteína foi avaliada de maneira pareada e não apresentou mudança significativa no antes e depois, havendo, contudo, forte correlação com o LDL-colesterol. Conclusão: Pacientes candidatos à cirurgia bariátrica frequentemente apresentam deficiências nutricionais anteriores ao procedimento com riscos aumentados no período pós-cirúrgico quando não aderem ao acompanhamento nutricional adequado.
Dislipidemias. Vitamina B12. Homocisteína. Proteína $\mathrm{C}$ reativa.

\section{INTRODUCTION}

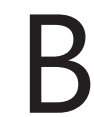
ariatric surgery is indicated for obese patients with a body mass index (BMI) greater than $40 \mathrm{~kg} / \mathrm{m}^{2}$, or even between $35-39.9 \mathrm{~kg} / \mathrm{m}^{2}$ with comorbidities. The indication has grown significantly. In Brazil it was performed 60,000 operations in 2010, representing an increase of $33 \%$ the previous year, and $275 \%$ compared to $2003^{12,24}$.

Several diseases are associated with obesity and dyslipidemia are among the most frequent ones. Both conditions have considerable potential of morbidity and mortality in relation to altered levels of serum lipids, as well as the increased risk of atherogenesis, systemic arterial hypertension, insulin resistance and coagulation disorders. The prevalence of dyslipidemia is variable among patients with morbid obesity (19.0-82.9\%). Some studies consider dyslipidemia when only one of the serum lipid levels are alterated: total cholesterol, high density lipoprotein (HDL cholesterol), low density lipoproteins (LDL-cholesterol) and triglycerides, also known as primary dyslipidemia; while others, only when there is mixed dyslipidemia (hypercholesterolemia associated with hypertriglyceridemia) ${ }^{15,19,27}$.

The objective of this study was to compare serum biochemical levels in pre- and postoperative of bariatric surgery. 
METHODS

This research was authorized by the Committee of Ethics and Research of Positivo University, under $n^{\circ}$. 1.073.415, meeting the requirements of resolution 466/2012 from the National Commission on Ethics in Research of CONEP4.

A cross-sectional, retrospective and non-concurrent study was held in a private clinic for patients monitoring pre- and postoperative (PO) of bariatric surgery at the Clinic Baretta, Curitiba, PR, Brazil. The analysis obtained was through investigation of the records of patients undergoing gastroplasty from January to September 2015, in the pre- and postoperative period (nutritional monitoring within the first postoperative year) and data collection was held between the months of July to September 2015. For the sample, 29 charts of patients of both genders were selected, with ages between 18-70 years old, which underwent Roux-en-Y gastric bypass for obesity correction. The analysis considered the biochemical assessment of total cholesterol (TC), high density lipoprotein $(\mathrm{HDL}-\mathrm{C})$, low density lipoprotein (LDL-cl), triglycerides (TG), C-reactive protein (CRP), serum dosages of vitamin $B_{12^{\prime}}$ folic acid, serum homocysteine, iron and calcium, in two moments: preoperative and the first nutritional monitoring consultation in postoperative. Were considered: gender, age, weight, height, and current $\mathrm{BMI}$ in the same monitoring periods.

For the values of serum lipid profile, a dosage of TC equal to $200 \mathrm{mg} / \mathrm{dl}$ was used, having as preventive goal those distributed in LDL-cholesterol $<160 \mathrm{mg} / \mathrm{dl}$, triglycerides $<150$ $\mathrm{mg} / \mathrm{dl}$ and $\mathrm{HDL}$-cholesterol $>40 \mathrm{mg} / \mathrm{dl}$, in men, and $>50 \mathrm{mg} /$ $\mathrm{dl}$ in women, classifying them in desirable, high and low, and blood glucose of $70-100 \mathrm{mg} / \mathrm{dl}^{24}$

For dosages of vitamin $B_{12}$ and folate, the following reference values were given: 200 to $900 \mathrm{pg} / \mathrm{ml}$ and 9,8 and $16,2 \mathrm{nmol} / \mathrm{l}$ respectively ${ }^{10,29}$. For homocysteine values $(\mathrm{Hcy})$, the same adopted for the population under 70 years was established as reference: 6-12 $\mu \mathrm{mol} / \mathrm{l}$ for women and 8-14 $\mu \mathrm{mol} / \mathrm{l}$ for $\mathrm{men}^{29}$.The dosage adopted for serum calcium (serum or plasma) was $8,8-11,0 \mathrm{mg} / \mathrm{dl}$. The values adopted for serum iron according to gender were, for men, $59-158 \mathrm{mcg} / \mathrm{dl}$ and, for women, $37-145 \mathrm{mcg} / \mathrm{dl}^{29}$. For C-reactive protein the values considered were $<1.0 \mathrm{mg} / \mathrm{l}$ or $<0.1 \mathrm{mg} / \mathrm{dl}$ for low risk ${ }^{18}$.

Data collection considered biochemical results coming from more than one clinical analysis laboratory, and were excluded the medical charts incompletely fulfilled.

\section{Statistical analysis}

Were correlated the homocysteine serum levels with the risk of cardiovascular diseases in gastrectomized patients, seeking to identify possible nutritional inadequacies relating them to the levels of vitamin $B_{12}$ and folic acid in this population, comparing the $\mathrm{C}$-reactive protein values in the pre- and postoperative. Statistical analysis was performed using R-tool (R Development Core Team 2015, version 3.2.2). For the descriptive analysis, the package cvforecastLopes ${ }^{14}$ was used.

RESULTS

The sampling was composed by 29 patients of both genders, 26 women and three men. The Table 1 shows that the average age of the population was 35.86 years old (18$67)$. Faced with the analysis of the average weight variable, there was a significant reduction after surgery of $108.53 \mathrm{~kg}$ to $78.69 \mathrm{~kg}$ with standard deviation of $16.03 \mathrm{~kg}$ and 15.07 $\mathrm{kg}$, respectively. Consequently, the average BMI presented reduction from $40.06 \mathrm{~kg} / \mathrm{m}^{2}$ to $28.75 \mathrm{~kg} / \mathrm{m}^{2}$, causing the rating decrease from morbidly obese to overweight $(S D=5.01$ and 4.51 ), representing a decrease of $28.23 \%$ in the overall average weight. By subtracting the standard deviation of the average in the postoperative period, the BMI reached 24.24 $\mathrm{kg} / \mathrm{m}^{2}$, expressing as final results the following classifications: $27 \%$ of patients remained in the obesity range, $51.7 \%$ with overweight and $20.7 \%$ in the range of eutrophy.

TABLE 1 - Age and comparison among values of weight, height and $\mathrm{BMI}$ in pre- and postoperative periods

\begin{tabular}{|c|c|c|c|c|c|c|}
\hline \multirow{2}{*}{ Variable } & \multicolumn{2}{c}{ Average (BI 95\%) } & \multicolumn{2}{c|}{ Median } & \multicolumn{3}{c|}{$\begin{array}{c}\text { Standard } \\
\text { deviation }\end{array}$} \\
\cline { 2 - 7 } & Before & After & Before & After & Before & After \\
\hline Age $^{*}$ & $35.86(30.7 ; 40.4)$ & $35.9(30.7 ; 40.6)$ & 31 & 31 & 13.57 & 13.57 \\
\hline Weight $(\mathrm{kg})$ & $108.5(103.2 ; 114.3)$ & $78.7(72.9 ; 83.6)$ & 107 & 74.3 & 16.03 & 15.07 \\
\hline Heigth $(\mathrm{m})$ & $164.5(161.4 ; 167.4)$ & $164.5(161.5 ; 167)$ & 163 & 163 & 8.08 & 8.08 \\
\hline BMI $\left(\mathrm{kg} / \mathrm{m}^{2}\right)$ & $40.1(38.2 ; 41.5)$ & $28.7(27.1 ; 30.1)$ & 39.4 & 28 & 5.01 & 4.51 \\
\hline
\end{tabular}

$B=$ before; $A=$ after; ${ }^{*}$ years old

The average value of total cholesterol in the studied group had a decrease of 19\%, going from $200.78 \mathrm{mg} / \mathrm{dl}$ to $162.63 \mathrm{mg} / \mathrm{dl}$ in average; however, when assessing the values of $\mathrm{HDL}-\mathrm{C}$, no significant alterations were observed. The LDL-C variable presented a significant difference with decrease of approximately $30.3 \mathrm{mg} / \mathrm{dl}$ after the gastroplasty.

For the assessment of the lipid profile of patients that underwent the gastric bypass in the pre- and postoperative periods, the covariates TC (Wilcoxon, $\mathrm{p}=0.0000$ ), $\mathrm{LDL}$ (test $\mathrm{t}$, $p=0.0001$ ) and HDL (Wilcoxon, $p=0.9184$ ) were applied.

As to the LDL-c before surgery, $44.8 \%$ of patients were presented within the ranges of $86.3-121 \mathrm{mg} / \mathrm{dl}$; from these, $10.3 \%$ raised to the range $121-155 \mathrm{mg} / \mathrm{dl}$ and $17.2 \%$ lowered to the range $51.7-86.3 \mathrm{mg} / \mathrm{dl}$ (Table 2).

TABLE 2 - Ranges of TC, LDL-C, before and after the procedure

\begin{tabular}{|c|c|c|c|c|c|}
\hline \multirow{3}{*}{ Before } & \multicolumn{5}{|c|}{ Total cholesterol per ranges $(\mathrm{mg} / \mathrm{dl})$} \\
\hline & \multicolumn{5}{|c|}{ After } \\
\hline & (114.166](\%) & $(166.217](\%)$ & (217.268](\%) & $(268.320](\%)$ & $\sum(\%)$ \\
\hline$(114.166]$ & $5(17.2)$ & $0(0.0)$ & $0(0.0)$ & $0(0.0)$ & $5(17.2)$ \\
\hline$(166.217]$ & $10(34.5)$ & $7(24.1)$ & $0(0.0)$ & $0(0.0)$ & $17(58.6)$ \\
\hline$(217.268]$ & $2(6.9)$ & $3(10.3)$ & $0(0.0)$ & $0(0.0)$ & $5(17.2)$ \\
\hline (268.320] & $0(0.0)$ & $2(6.9)$ & $0(0.0)$ & $0(0.0)$ & $2(6.9)$ \\
\hline$\Sigma$ & $17(58.6)$ & $12(41.4)$ & $0(0.0)$ & $0(0.0)$ & $29(100)$ \\
\hline \multirow{3}{*}{ Before } & \multicolumn{5}{|c|}{ LDL per ranges $(\mathrm{mg} / \mathrm{dl})$} \\
\hline & \multicolumn{5}{|c|}{ After } \\
\hline & $(51.7,86.3](\%)$ & $(86.3,121](\%)$ & $(121.155](\%)$ & (155.190] (\%) & $\sum(\%)$ \\
\hline$(51.7 .863]$ & $0(0.0)$ & $0(0.0)$ & $0(0.0)$ & $0(0.0)$ & $0(0.0)$ \\
\hline (86.3.121] & $5(17.2)$ & $5(17.2)$ & $3(10.3)$ & $0(0.0)$ & $13(44.8)$ \\
\hline (121.155] & $3(10.3)$ & $4(13.8)$ & $1(3.4)$ & $0(0.0)$ & $8(27.6)$ \\
\hline (155.190] & $1(3.4)$ & $3(10.3)$ & $3(10.3)$ & $1(3.4)$ & $8(27.6)$ \\
\hline$\Sigma$ & $9(31)$ & $12(41.4)$ & 7 (24.1) & $1(3.4)$ & $29(100)$ \\
\hline
\end{tabular}

$B=$ before; $A=$ after; $\Sigma=$ sum

By seeing the margins in Table 2, it is possible to conclude that, before the operation, $58.6 \%$ of patients had total cholesterol in the range of $166-217 \mathrm{mg} / \mathrm{dl}$ and, among these, $34.5 \%$ decreased to the range of $114-166 \mathrm{mg} / \mathrm{dl}$ in postoperative period. From $6.9 \%$ in the higher range, from $268-320 \mathrm{mg} / \mathrm{dl}$ all of them decreased to $166-217 \mathrm{mg} / \mathrm{dl}$.

Indicators of vitamin $\mathrm{B}_{12}$, total triglycerides, folic acid, serum glucose, serum iron and calcium, and $C$-reactive protein (CRP) also presented some change (Table 3).

In this study in the preoperative period the average of serum levels of vitamin $B_{12}$ was $341.9 \mathrm{pg} / \mathrm{ml}$. Afterwards, $667.2 \mathrm{pg} / \mathrm{ml}$ was observed, which is considered normal level.

Triglyceride levels in preoperative period were in the range of $129.6-173.3 \mathrm{mg} / \mathrm{dl}$, and in the postoperative had considerable reduction, $81.9-105.3 \mathrm{mg} / \mathrm{dl}$.

The analysis of levels of folic acid was $7.6-10.9 \mathrm{nmol} / \mathrm{l}$ before the operation and 10.7-14.6 nmol/l after surgery, demonstrating none significant improvement. 
Serum iron was in the range of $80.7-102.9 \mu \mathrm{g} / \mathrm{dl}$ and after the intervention dropped down to $68.1-86.5 \mu \mathrm{g} / \mathrm{dl}$.

The analysis of calcium had no significant change, staying in the range of $8.4-9.4 \mathrm{mg} / \mathrm{dl}$ and $8.9-9.3 \mathrm{mg} / \mathrm{dl}$ in the pre- and postoperative periods, respectively.

TABLE 3 - Comparison among values of vitamin B12, TG homocysteine, HDL-c, LDL-c, folic acid, CRP, glucose, serum iron and calcium in the pre- and postoperative periods

\begin{tabular}{|c|c|c|c|c|c|c|}
\hline \multirow[t]{2}{*}{ Variable } & \multicolumn{2}{|c|}{ Average (BI 95\%) } & \multicolumn{2}{|c|}{ Median } & \multicolumn{2}{|c|}{$\begin{array}{l}\text { Standard } \\
\text { deviation }\end{array}$} \\
\hline & B & A & B & A & B & A \\
\hline Vit. B12 & $341.9(295.1 ; 383.3)$ & $667.2(499.5 ; 807)$ & 300 & 607 & 125.5 & 431.5 \\
\hline TG & 149.8 (129.6; 173.3) & $94.4(81.9 ; 105.3)$ & 149 & 92 & 58.04 & 31.16 \\
\hline Homocysteine & $8.99(8.2 ; 9.8)$ & $8.6(7.8 ; 9.4)$ & 9.1 & 8.3 & 2.21 & 2.27 \\
\hline $\mathrm{HDL}$ & $44.69(39.9 ; 48.6)$ & $45.3(40.5 ; 49.8)$ & 43 & 41.0 & 11.77 & 13.45 \\
\hline LDL & $131.9(120.4 ; 143.1)$ & $101.6(89.7 ; 113.7)$ & 131 & 95.4 & 33.02 & 32.19 \\
\hline Folic acid & $9.3(7.6 ; 10.9)$ & $12.5(10.7 ; 14.6)$ & 8.40 & 13.9 & 4.63 & 5.65 \\
\hline CRP & $8.4(6.2 ; 10.5)$ & $3.5(2.4 ; 4.5)$ & 8.80 & 3.4 & 6.31 & 3.17 \\
\hline Glucose & $90.3(85.1 ; 94.9)$ & $81.7(78.8 ; 84.7)$ & 86 & 81 & 12.52 & 7.96 \\
\hline $\mathrm{Fe}$ & $92.1(80.7 ; 102.9)$ & $76.9(68.1 ; 86.5)$ & 84 & 82 & 31.25 & 25.41 \\
\hline $\mathrm{Ca}$ & $8.8(8.4 ; 9.4)$ & $9.1(8.9 ; 9.3)$ & 9.10 & 9.2 & 1.50 & 0.46 \\
\hline
\end{tabular}

$B=$ before; $A=$ after

To assess the inflammatory process caused by obesity from the CRP levels, comparing the pre- and post-surgery periods, the variable was analyzed in both. In Table 4 it is possible to see CRP levels lower than $6.56 \mathrm{mg} / \mathrm{dl}$ were present in $41.4 \%$ before, and after they came to $34.5 \%$. In the range $6.56-13.1 \mathrm{mg} / \mathrm{dl}$, the levels were $44.8 \%$ before and came to $6.9 \%$, evidencing that $37.9 \%$ of patients presented decrease in the levels of this protein.

TABLE 4 - Distribution of pre- and post levels of CRP

\begin{tabular}{|c|c|c|c|c|c|}
\hline \multirow{3}{*}{ Before } & \multicolumn{5}{|c|}{ CRP per ranges $(\mathrm{mg} / \mathrm{dl})$} \\
\hline & \multicolumn{5}{|c|}{ After } \\
\hline & $(0.6,56](\%)$ & $(6.56,13.1](\%)$ & $(13.1,19.7](\%)$ & $(19.7,26.3](\%)$ & $\Sigma(\%)$ \\
\hline$(0.6,56]$ & $10(34.5)$ & $2(6.9)$ & $0(0.0)$ & $0(0.0)$ & $12(41.4)$ \\
\hline$(6.56,13.1]$ & $11(37.9)$ & $2(6.9)$ & $0(0.0)$ & $0(0.0)$ & $13(44.8)$ \\
\hline$(13.1,19.7]$ & $2(6.9)$ & $0(0.0)$ & $0(0.0)$ & $0(0.0)$ & $2(6.9)$ \\
\hline$(19.7,26.3]$ & $0(0.0)$ & $2(6.9)$ & $0(0.0)$ & $0(0.0)$ & $2(6.9)$ \\
\hline$\Sigma$ & $23(79.3)$ & $6(20.7)$ & $0(0.0)$ & $0(0.0)$ & $29(100)$ \\
\hline
\end{tabular}

$B=$ before; $A=$ after; $\Sigma=$ sum

In this study, the Hyc variable was tested in a paired manner and did not present a significant change before and after, due to the number of the sample; however, it showed a strong correlation with the LDL-C, justified by the fact that homocysteine accelerates the oxidation of LDL-C, further increasing the risk of cardiovascular disease.

TABLE 5 - Homocysteine and LDL-c per range

\begin{tabular}{cc|c|c|c|c|} 
Homocysteine & \multicolumn{5}{c|}{ LDL-c (mg/dl) } \\
\cline { 2 - 6 }$($ umol/l) & $(51.7,86.3](\%)$ & $(86.3,121](\%)$ & $(121,155](\%)$ & $(155,190](\%)$ & $\Sigma(\%)$ \\
\hline$(4.03,6.53]$ & $4(13.8)$ & $0(0.0)$ & $1(3.4)$ & $0(0.0)$ & $5(17.2)$ \\
\hline$(6.53,9.02]$ & $3(10.3)$ & $8(27.6)$ & $2(6.9)$ & $0(0.0)$ & $13(44.8)$ \\
\hline$(9.02,11.5]$ & $1(3.4)$ & $4(13.8)$ & $2(6.9)$ & $0(0.0)$ & $7(24.1)$ \\
\hline$(11.5,14]$ & $1(3.4)$ & $0(0.0)$ & $2(6.9)$ & $1(3.4)$ & $4(13.8)$ \\
\hline$\Sigma$ & $9(31)$ & $12(41.4)$ & $7(24.1)$ & $1(3.4)$ & $29(100)$ \\
\hline
\end{tabular}

$B=$ before; $A=$ after; $\Sigma=$ sum. Fisher's exact test. $p=0.0292$

\section{DISCUSSION}

The weight loss following gastric bypass is accompanied by sharp improvement of all obesity-related comorbidities. With the weight loss an improvement in insulin resistance occurs, as well as reduction in adiposity and increased metabolic control ${ }^{20}$, thereby, it reduces the cardiovascular risk factors. Surgical intervention in just three months proved to be effective in improving the lipid profile and, consequently, major cardiovascular risk factors. This improvement observed by reduction of TC, LDL-C, TG was also observed in other studies. Asztalos et al. ${ }^{2}$ demonstrated improvement in concentrations of LDL-C and TG from the first postoperative month. Nassif et al. ${ }^{17}$ found reduction in TC, LDL-C and TG, after four months. However, Vila et al. ${ }^{31}$ reported reduction of TG, only starting from the sixth month.

In the early postoperative period may occur some nutritional complications such as vomiting. diarrhea and dumping syndrome ${ }^{5}$.

The vitamin $B_{12^{\prime}}$ as well as iron and folic acid, are essential for cell development and division, as well as for the production of red blood cells, genetic material and myelin. The nutritional deficit that entails such a situation can be explained by lack of food and adequate supplementation in the preoperative period. Their deficiencies can cause pernicious anemia. neurological symptoms and weakness ${ }^{5}$.

The TG is formed from carbohydrates and stored in cells as caloric reserve, being used for energy in food deprivation periods. Their excess can cause inflammatory cytokines that are commonly increased in obesity. According to studies in the literature, low levels of TG show lower risk for cardiovascular disease ${ }^{30}$

The absorption of folic acid takes place preferably in the duodenum; however, it can also occur along the entire length of the small intestine, as a result of postoperative physiological adaptation. The vitamin $B_{12}$ is required for the conversion of methyl tetrahydrofolic acid (inactive) into tetrahydrofolic acid (active). Therefore, deficiency of vitamin $B_{12}$ may result in folic acid deficiency ${ }^{3}$.

Oliveira et al. demonstrated that conventional therapies are ineffective when compared to the effectiveness that gastric bypass patients have in overweight and impaired glucose metabolism disorders. A possible explanation for the improvement of blood glucose would be the immediate and severe deprivation of nutrients that occurs after surgery. According to Carvalho et al. ${ }^{5}$ studied 47 obese patients that underwent Roux-en-Y gastric bypass; among them, 15 had diabetes and five glucose intolerance. One year after the surgery; the 20 patients had normal levels of fasting plasma glucose and glycosylated hemoglobin. Results show that there are benefits obtained in glycemic control with gastric bypass, even with non-exclusive indication regarding the glycemic status.

With respect to serum iron, the levels found are in agreement with the literature, since they are affected due to decrease in food intake supplies, decreased production of gastric acid, hampering digestion and also due to the modification of the duodenum and proximal jejunum, primary absorption sites, where most of the iron is absorbed. It is important that the serum iron levels be monitored regularly. Some studies suggest that vitamin $C$ supplementation can help in iron deficiency for assisting in the absorption process ${ }^{6,23}$.

Regarding the mineral calcium, obese people may have lower levels even before the surgery, and possible explanations include the reduction of physical activity with less exposure to sunlight and body fat storage increase with reduced bioavailability. The calcium absorption occurs in the small intestine and, even in patients with normal calcium levels, after gastric bypass the levels are affected, thus having depletion of this ion with consequences in bone architecture ${ }^{7}$. According with the literature, the data found are related to the surgical technique, because Roux-en-Y gastric bypass has no great result compared to other techniques ${ }^{16}$.

Epidemiological studies have documented recently that mild elevations in concentrations of CRP in the acute stage, 
even within the reference range, may predict the onset of cardiovascular disease and diabetes ${ }^{1}$. Obese patients may have high levels of CRP due to increased production of interleukin- 6 and tumor necrosis factor in adipocytes, regulating hepatic production of CRP and inducing a state of chronic low-grade inflammation. Some evidences suggest that after gastrectomy the serum levels of CRP decrease $65 \%$, (in average) according to the weight loss ${ }^{25}$. The reduction of inflammatory activity observed by decreasing levels of CRP in this study corroborates the results demonstrated by the researcher, who observed a decrease in the amounts of CRP provided by the occurrence of weight loss in the research patients ${ }^{8}$.

Homocysteine is a toxic amino acid derived from the amino acid methionine sulphide found in proteins from meat, dairy products, eggs, fishes and other sources. The increase of its levels has been reported after bariatric surgery. Its plasma concentration is influenced both by nutritional factors as hereditary ones, as well as pathological conditions such as decreased renal function and hypothyroidism ${ }^{28}$. Some researchers emphasize the role of Hcy only as a marker of folic acid deficiency and vitamin $\mathrm{B}_{12}$ i others point out that the increase in their levels causes oxidative stress, which promotes neurological and vascular damage at the central leve ${ }^{27}$. High levels of Hcy may indicate not only low levels of folate, but also an independent risk factor for cardiovascular disease and/or oxidative stress. The vitamins $B_{6^{\prime}} B_{12}$ and folic acid are responsible for maintaining the concentration of homocysteine normalized ${ }^{22}$.

It is important to detect nutritional deficiencies in preoperative period, even if laboratory tests show limitations. This avoids difficulties on treatment in the postoperative period and, also, to not attribute mistakenly the micronutrient deficiency to the surgery ${ }^{26}$.

The most common deficiencies include iron, folic acid and vitamin $B_{12}$ deficiency, due to the limited intake of animal proteins, due to the reduction of gastric secretions that impair the cleavage of the vitamin from the protein and inappropriate secretion of intrinsic factor. After the surgery, monitoring the levels of these elements is necessary ${ }^{21}$.

Changes in eating habits in the postoperative phase are factors that contribute to the emergence of the deficiencies of vitamins and minerals. The reduced intake of iron-rich foods, combined with the physiological changes brought about by the surgery, are considered a risk factor for development of anemia ${ }^{11}$.

According to Leiro et al. ${ }^{12}$ nutrient supplementation after bariatric surgery is needed in all surgical techniques. In 2013 the guidelines given by American Association of Endocrinologists, the Obesity Society and the American Society for Metabolic and Bariatric Surgery have been updated, including 74 recommendations for patients in pre- and postoperative periods of bariatric surgery. In the case of gastric bypass, should be given a particular importance with regard to the possible deficiencies of iron, calcium, vitamin D, vitamin B1, vitamin B12 and folate ${ }^{3}$.

Micronutrient deficits are the main changes that jeopardize the success of surgical procedures. Nutritional supplementation in the long term, although much emphasized, still represents an obstacle to the success of surgical treatment of obesity. The start of supplementation or reposition of iron in an isolated manner has been recommended right after the hospital discharge, or 48 hours after the surgery. The use of preventive supplementation should compose the care protocol for all patients undergoing (or undergone) bariatric surgery. The treatment of nutritional deficiencies should consider mega doses of micronutrients due to lower bioavailability arising out of the physiological changes caused by surgical techniques ${ }^{3}$.

For greater success after surgery it is necessary to, in the preoperative period, strengthen the patient's perception that weight loss is possible when the energy balance becomes negative. It is required to identify dietary mistakes and disorders, inform the significant changes that the patient will face, start adjustments in the individual's power to promote real expectations of weight loss, prepare the patient for new food and habits and check the patient's potential for success operation ${ }^{15}$. According to Endevelt et al. ${ }^{9}$ the follow-up of a nutritionist in the postoperative period is important. What determines the weight loss after surgery are the factors involved, and must to be taken into account the monitoring of surgery in the long term as well, to prove the benefits of the procedure. ${ }^{23}$ The research has shown significant reduction of BMI and nutritional deficiencies in patients with at least two follow-ups after the surgery, as well as improvement in lipid metabolism and in reducing the risk of cardiovascular disease.

\section{CONCLUSION}

The bariatric surgery was effective for weight loss and improvement of lipid metabolism. There was lack of vitamin $B_{12}$ and folic acid. The calcium remained within normal limits. The C-reactive protein decreased after the surgery, demonstrating decrease in inflammatory process.

\section{REFERENCES}

1. Adriana R., Norton Rocksane C., Rossetti Márcia B., Leão Ennio, Mendes Ricardo P.. C-Reactive protein as an indicator of low intensity inflammation in children and adolescents with or without obesity. J. Pediatr. (Rio J.)[Internet]. 2007 Oct [cited 2015 Oct 13] ; 83( 5 ): 477-480

2. Asztalos BF, Swarbrick MM, Schaefer EJ, Dallal GE, Horvath KV, Ai M, et al. Effects of weight loss, induced by gastric bypass surgery, on HDL remodeling in obese women. J. Lipid Res. [Internet] 2010 Aug [cited 2015 Oct 25] ; 51(8): 2405-2412.

3. BordaloLA, TeixeiraTFS, BressanJ, MourãoDM, Deficiênciasnutricionais após cirurgia bariátrica, Acta Med Port. [Internet]. 2011 [cited 2015 Oct 17]; 24(4):1021-1028.

4. Brasil, Resolução $N^{\circ} 466$, de 12 de dezembro de 2012. Publicada no DOU n 12.,Seção.1; 2013; 59.

5. Carvalho IR, Loscalzo IT, Freitas MF, Jordão RE, Friano Tde C. Incidence of vitamin B12 deficiency in patients submitted to Fobi-Capella Rouxen-Y bariatric surgery. Arq Bras Cir Dig. 2012 Jan-Mar;25(1):36-40.

6. Carvalho PS, Moreira CL, Barelli Mda C, Oliveira FH, Guzzo MF, Miguel GP, Zandonade E. Can bariatric surgery cure metabolic syndrome? Arq Bras Endocrinol Metabol. 2007 Feb;51(1):79-85.

7. Davies DJ, Baxter JM, Baxter JN. Nutritional deficiencies after bariatric surgery. Obes Surg. 2007 Sep;17(9):1150-8.

8. Devaraj $\mathrm{S}$, Singh $\mathrm{U}$, Jialall .The evolving role of $\mathrm{C}$-reactive protein in atherothrombosis. Clin Chem. [Internet].2009;Feb [cited 2015 Oct 26];55(2):229-38.

9. Endevelt R, Ben-Assuli O, Klain E, Zelber-Sagi S. The role of dietician follow-upinthesuccess ofbariatricsurgery.SurgObesRelatDis. [Internet]. 2013 Nov [cited 2015 Nov 28]; 9 (6): 963-8.

10. Fábregas BC, Vitorino FD, Teixeira AL. Deficiência de vitamina B12 e transtorno depressivo refratário. J. Bras. psiquiatr. [Internet]. 2011 May [cited 2015 Nov 13]; 60( 2 ): 141-143.

11. Faé $C$, Liberali $R$, Coutinho VF. Deficiência de nutrientes a longo prazo no pós-operatório de cirurgia bariátrica - Revisão sistemática. Sabios-Revista De Saúde E Biologia. [Internet] 2015Ago [cited 2015 Oct 23]; 10(2): 46-53.

12. Leiro LS, Melendez-Araújo MS. Diet micronutrient adequacy of women after 1 year of gastric bypass. Arq Bras Cir Dig. 2014;27 Suppl 1:21-5.

13. Lins DC, Campos JM, de Paula PS, Galvão-Neto M, Pachu E, Cavalcanti $\mathrm{N}$, Ferraz ÁA. C-reactive protein in diabetic patients before gastric bypass as a possible marker for postoperative complication. Arq Bras CirDig.2015:28Suppl 1:11-4.doi:10.1590/S0102-6720201500\$100005.

14. Lopes JE. Séries temporais como ferramentas de tomada de decisão em bi um framework para forecast automatizado. [Internet]. 2015 [cited 2015 Nov 09]; Disponível em: <https://github.com/evandeilton/ cvforecast>.

15. Magno FC, da Silva MS, Cohen L, Sarmento LD, Rosado EL, Carneiro JR. Nutritional profile of patients in a multidisciplinary treatment program for severe obesity and preoperative bariatric surgery. Arq Bras Cir Dig. 2014;27 Suppl 1:31-4. 
16. MoralesCLP,AlexandreJG,PrimS,AmanteLN.Perioperativecommunication from the perspective of patients undergoing bariatric surgery.Texto contexto - enferm. [Internet]. 2014 June [cited 2015 Oct 04] ; 23( 2 ): 347-355.

17. Nassif PAN, Lopes AD, Lopes GL, Martins PR, Pedri LE, Varaschim M, BoppDS.Alteraçõesnos parâmetros prée pós-operatórios de pacientes com síndrome metabólica, submetidos a Bypass gastrointestinal em Y de Roux. ABCD, arq. bras. cir. dig. [Internet]. 2009 Sep [cited 2015 Oct 04]; 22(3): 165-170.

18. National Academy of Clinical Biochemistry (NACB) Medicine Practice Guideline.ClinChem 2009; 55(2): 378

19. Oliveira LF, Tisott CG, Silvano DM, Campos CM, do Nascimento RR. Glycemic behavior in 48 hours postoperative period of patients with type 2 diabetes mellitus and non diabetic submitted to bariatric surgery. Arq Bras Cir Dig. 2015;28 Suppl 1:26-30. doi: 10.1590/S01026720201500 S100009.

20. Oliveira MRM, Fortes RC. Efeitos da Gastroplastia Redutora com Derivação Intestinal em Y de Roux sobre a obesidade grave e Síndrome Metabólica: uma revisão de literatura. Com. Ciências Saúde. [Internet]. 2014 Feb [cited 2015 Nov 10] ; 24(3): 267-280.

21. Ramos NM, Magno FC, Cohen L, Rosado EL, Carneiro JR. Weight loss and nutritional anemia in patients submitted to Roux-en-Y gastric bypass on use of vitamin and mineral supplementation. Arq Bras Cir Dig. 2015;28(1):44-7. doi: 10.1590/S0102-67202015000100012.

22. Santos CRB, Portella ES, Avila SS, Soares EA. Fatores dietéticos na prevenção e tratamento de comorbidades associadas à síndrome metabólica. Rev. Nutr. [Internet]. 2006 June [cited 2015 Nov 11];19( 3 ): $389-40$
23. Santos TD, Burgos MG, de Lemos MC, Cabral PC. Clinical and nutritional aspects in obese women during the first year after roux-en-y gastric bypass. Arq Bras Cir Dig. 2015;28 Suppl 1:56-60. doi: 10.1590/S01026720201500 S100016.

24. SBCBM - Sociedade Brasileira de Cirurgia Bariátrica e Metabólica. Consenso BrasileiroMultissocietárioem Cirurgia da Obesidade.RETIRAR

25. Scibora LM, Ikramuddin S, Buchwald H, Petit MA. Examining the Link Between Bariatric Surgery, Bone Loss, and Osteoporosis: a Review of Bone Density Studies. Obes Surg. [Internet]. 2012; Apr [cited 2015 Nov 11]; 22(4):654-667.(ReTIRAR)

26. Shankar P, Boylan M, Sriram K. Micronutrient deficiencies after bariatric surgery.Nutrition. [Internet].2010Dec[cited2015Nov 10];26(11):1031-7.

27. Silva EN, Sanches MD. Perfil lipídico de obesos antes e após a derivação gástrica a Fobi-Capella. Rev. Col. Bras. Cir. [Internet]. 2006 Apr [cited 2015 Oct 20];33(2): 91-95.

28. VannucchiH,MeloSS. Hiper-homocisteinemiaerisco cardiometabólico. ArqBrasEndocrinoMetab. [Internet]. 2009 July [cited 2015 Nov 08]; 53(5):540-549.

29. Vannucchi H, Monteiro TH. Funções Plenamente Reconhecidas de Nutrientes Ácido Fólico. Brasil International Life Sciences Institute do Brasil.[Internet].2010 Feb [cited 2015 Nov 15];10(3): 7.

30. Vieira RAL, Silva RA, Tomiya MTO, Lima DSC. Efeito da cirurgia bariátrica sobre o perfil lipídico mais aterogênico em curto prazo. Nutr. clín. diet hosp. [Internet]. 2015 Feb [cited 2015 Nov 05]; 35(1): 24-31.

31. Vila M, Ruíz O, Belmonte M, Riesco M, Barceló A, Perez G et al. Changes in lipid profile and insulin resistance in obese patients afterScopinarobiliopancreatic diversion. ObesSurg 2009 Dec [cited 2015 Nov 10]; 19(3): 299-306. 